NOTE

\title{
White tail disease of the giant freshwater prawn Macrobrachium rosenbergii in Thailand
}

\author{
Kalidoss Yoganandhan ${ }^{1,2, *}$, Manee Leartvibhas ${ }^{3}$, Supamas Sriwongpuk ${ }^{4}$, \\ Chalor Limsuwan ${ }^{4}$ \\ ${ }^{1}$ Centex Shrimp, Faculty of Science, Mahidol University, Rama 6 Road, Bangkok 10400, Thailand \\ ${ }^{2}$ National Center for Genetic Engineering and Biotechnology, National Science and Technology Development Agency, \\ Phahonyothin Road, Klong 1, Klong Luang, Pathumthani 12120, Thailand \\ ${ }^{3}$ Shrimp Culture Research Center, Charoen Pokphand Foods Public Company, 82/2 Rama 2 Rd., Samut Sakhon 74000 , \\ Thailand \\ ${ }^{4}$ Department of Fisheries Biology, Faculty of Fisheries, Kasetsart University, Pahonyothin Rd., Bangkok 19000, Thailand
}

\begin{abstract}
White tail disease (WTD) of the freshwater prawn Macrobrachium rosenbergii has recently been the cause of high mortalities in Thai prawn farms. The causative agents of this disease in other countries are $M$. rosenbergii nodavirus (MrNV) and extra small virus (XSV), which are usually detected using reverse transcriptase-polymerase chain reaction (RT-PCR) protocols. Using RT-PCR, most Thai post-larvae (PL) samples showing gross signs of WTD tested positive for MrNV but only a few were positive for XSV. In contrast, all tested brooder samples were positive for both MrNV and XSV. The possibility that brooders infected with MrNV and XSV could transmit the viruses to larvae and PL should be examined. Cloning, sequencing and comparison of deduced amino acid sequences of RT-PCR amplicons of WTD samples from Thailand with those of MrNV and XSV previously reported from the French West Indies and China revealed that the $M r N V$ were closely related but not identical while those from XSV were identical. This is the first report of $M r N V$ and XSV from Thailand.
\end{abstract}

KEY WORDS: White tail disease - Macrobrachium rosenbergii nodavirus · Extra small virus RT-PCR detection · Brooder

Resale or republication not permitted without written consent of the publisher

\section{INTRODUCTION}

Macrobrachium rosenbergii is a native species of Thailand and other Southeast Asian countries (New 1990). It is considered to be a moderately disease-resistant aquaculture species when compared to penaeid shrimp (Nash et al. 1987) and it has a high economic value. White tail disease (WTD) was first observed and reported in a hatchery in Guadeloupe; it was detected and reported later in Martinique, French West Indies (Arcier et al. 1999). It was then reported from Taiwan (Tung et al. 1999) and The People's Republic of China in Zhejiang, Jiangsu, Guangdong and Shanghai provinces (Qian et al. 2003, Sri Widada et al. 2003) and finally from India (Sahul Hameed et al. 2004a). Typical gross signs of diseases in infected post larvae (PL) are white discoloration in the abdominal (tail) region. The causative agents of WTD are $M$. rosenbergii nodavirus $(\mathrm{MrNV})$ and extra small virus (XSV) (Sri Widada et al. 2003).

$\mathrm{MrNV}$ is a small icosahedral non-enveloped virus, 26 to $27 \mathrm{~nm}$ in diameter that has been identified in the cytoplasm of connective tissue cells (Arcier et al. 1999). The capsid contains a single polypeptide of $43 \mathrm{kDa}$ (Romestand \& Bonami 2003). Based on these characteristics, the virus has been placed in the family Nodaviridae (Garzon \& Charpentier 1992, Van Regenmortel et al. 2000, Romestand \& Bonami 2003). 
Recently, XSV and MrNV have been purified (Bonami et al. 2005).

Detection methods for MrNV include a double antibody sandwich enzyme-linked immunosorbent assay (DS-ELISA) (Romestand \& Bonami 2003) and viral genome-based detection methods such as dot blot hybridization, in situ hybridization and reverse transcription-polymerase chain reaction (RT-PCR) amplification (Sri Widada et al. 2003). Similar genome-based detection methods are also available for XSV (Sri Widada et al. 2003, 2004). More recently a single-tube, duplex RT-PCR method has been developed for simultaneous detection of MrNV and XSV (Yoganandhan et al. 2005).

In the present study, farmed Macrobrachium rosenbergii showing gross signs of WTD and grossly normal brooders were tested for the presence of $M r N V$ and XSV by RT-PCR (Sahul Hameed et al. 2004a), and selected amplicons were sequenced and compared to those previously reported for $\mathrm{MrNV}$ and XSV from other countries.

\section{MATERIALS AND METHODS}

PL and brooders. Infected PL with prominent signs of whitish muscle in the abdominal region were collected from different locations in Thailand (Table 1). In addition, 3 samples of grossly normal, pond-reared brooders were collected from culture ponds in Rachaburi, Thailand. These samples were transported to the laboratory on dry ice and stored at $-20^{\circ} \mathrm{C}$.

Table 1. Macrobrachium rosenbergii. Detection of M. rosenbergii nodavirus (MrNV) and extra small virus (XSV) in samples of post-larvae (age in days) and brooder from different farms of Petachburi and Ayuthaya provinces, Thailand, using RT-PCR. -: negative; ++: infected; +++: severely infected

\begin{tabular}{|lrccc|}
\hline $\begin{array}{l}\text { Sample } \\
\text { Place of collection }\end{array}$ & Stage & Clinical signs & $\begin{array}{c}\text { RT-PCR } \\
\text { MrNV XSV }\end{array}$ \\
\hline (1) Petchaburi & $9 \mathrm{~d}$ & White muscle & +++ & - \\
(2) Petchaburi & $15 \mathrm{~d}$ & Pale white & - & - \\
(3) Petchaburi & $28 \mathrm{~d}$ & White muscle & - & - \\
(4) Petchaburi & $19 \mathrm{~d}$ & White muscle & +++ & - \\
(5) Petchaburi & $12 \mathrm{~d}$ & White muscle & +++ & - \\
(6) Ayuthaya & $20 \mathrm{~d}$ & White muscle & +++ & - \\
(7) Petchaburi & $21 \mathrm{~d}$ & White muscle & +++ & ++ \\
(8) Ayuthaya & $23 \mathrm{~d}$ & White muscle & - & - \\
(9) Ayuthaya & $10 \mathrm{~d}$ & White muscle & - & - \\
(10) Ayuthaya & $23 \mathrm{~d}$ & Pale white & - & - \\
(11) Ayuthaya & $13 \mathrm{~d}$ & White muscle & +++ & - \\
(12) Rachaburi & Brooder & - & ++ & ++ \\
(13) Rachaburi & Brooder & - & ++ & ++ \\
(14) Rachaburi & Brooder & - & ++ & ++ \\
(15) Rachaburi & 23 d & White muscle & ++ & +++ \\
\hline
\end{tabular}

Total RNA extraction. Whole PL (150 mg), hemolymph $(150 \mu \mathrm{l})$ or tissue fragments $(150 \mathrm{mg})$ from abdominal muscle tissue, tail muscle or pleopods were homogenized in $300 \mu \mathrm{l}$ of TN buffer (20 mM Tris $-\mathrm{HCl}$, $0.4 \mathrm{M} \mathrm{NaCl}, \mathrm{pH}$ 7.4). The homogenate was centrifuged at $12000 \times g$ for $15 \mathrm{~min}$ at room temperature (27 to $\left.30^{\circ} \mathrm{C}\right)$. The supernatant $(150 \mu \mathrm{l})$ was extracted using $1 \mathrm{ml}$ of TRIzol reagent (GIBCO-BRL) according to the manufacturer's protocol. RNA was precipitated from the aqueous phase with isopropanol, washed with $75 \%$ ethanol and dissolved in $50 \mu$ of TE buffer (10 mM Tris-HCl, 1 mM EDTA, pH 7.5).

RT-PCR. The oligonucleotide primers used for MrNV were (forward) 5'-GAT ACA GAT CCA CTA GAT GAC C-3' and (reverse) 5'-GAC GAT AGC TCT GAT AAT CC-3' while those for XSV were (forward) 5'-GGA GAA CCA TGA GAT CAC G-3' and (reverse) 5'-CTG CTC ATT ACT GTT CGG AGT C-3' (Sahul Hameed et al. 2004a). RT-PCR was carried out using a SuperScript ${ }^{\mathrm{TM}}$ 1-step RT-PCR system with a Platinum ${ }^{\circledR}$ Taq DNA Polymerase kit (Invitrogen ${ }^{\mathrm{TM}}$ ). Reactions were performed in $50 \mu \mathrm{l}$ RT-PCR buffer containing 20 pmol of each primer and RNA template and reverse transcription (RT) at $52^{\circ} \mathrm{C}$ for $30 \mathrm{~min}$, denaturation at $94^{\circ} \mathrm{C}$ for 2 min followed by 30 cycles of denaturation at $94^{\circ} \mathrm{C}$ for $40 \mathrm{~s}$, annealing at $55^{\circ} \mathrm{C}$ for $40 \mathrm{~s}$ and elongation at $68^{\circ} \mathrm{C}$ for $1 \mathrm{~min}$ with an additional elongation step at $68^{\circ} \mathrm{C}$ for $10 \mathrm{~min}$. The RT-PCR products were analyzed by electrophoresis in $0.8 \%$ agarose gels stained with ethidium bromide.

Sequencing and analysis. RT-PCR amplicons were purified from agarose gels using a QIA quick Gel Extraction Kit (QIAGEN) and sequenced by Macrogen South Korea. Amplicon sequences were converted to deduced amino acid sequences and aligned with other WTD sequences recorded at GenBank (Accession numbers AY222840 and NC_005095) using CLUSTAL W (1.82) (Thompson et al. 1994).

\section{RESULTS}

The typical gross signs of WTD in infected PL were lethargy and opaque abdominal muscles (white appearance). In all cases, mortality reached 100\% within 2 to $3 \mathrm{~d}$ after the first appearance of prawns with whitish muscles. The brooder samples were grossly normal and showed no signs of WTD.

Both post-larval and brooder samples tested positive for $\mathrm{MrNV}$ and XSV by RT-PCR (Table 1). Both viruses were detected in various organs of brooders (Fig. 1). Comparisons revealed that the 3 sequences of Thai MrNV (GenBank Accession number DQ189990) were identical and very similar (98\% cDNA identity) to those for $\mathrm{MrNV}$ reported from other geographical 


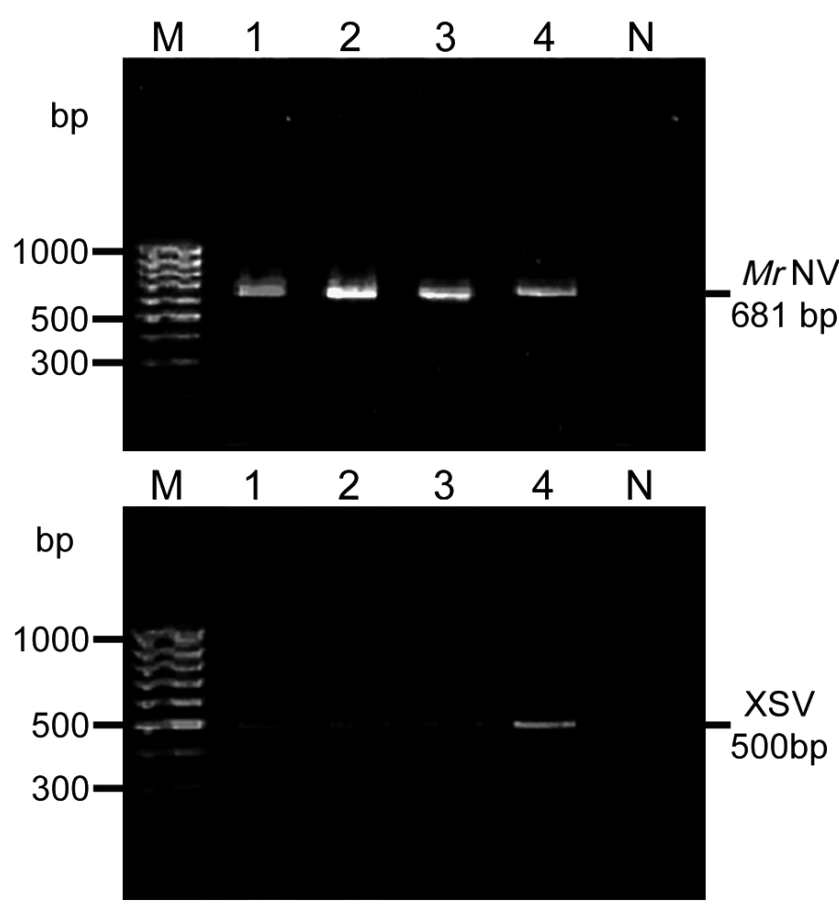

Fig. 1. Macrobrachium rosenbergii. Amplification of the RTPCR products of MrNV and XSV in farm-cultured brooders collected from Rachaburi, Thailand. Lane M: marker; Lane 1: hemolymph; Lane 2: gill tissue; Lane 3: tail muscle; Lane 4: pleopod; Lane N: negative control

locations. However, the minor changes in the Thai cDNA sequence led to 3 changes in deduced amino acids, one of which was a non-conservative change (Fig. 2). Thai XSV cDNA sequences (3) were also identical (GenBank Accession number DQ189991) and shared $98 \%$ identity to those reported from other regions. However, in contrast to Thai $M r N V$, deduced amino acid sequences showed $100 \%$ identity to those previously reported.

\section{DISCUSSION}

Sri Widada et al. (2003) suggested that both $\mathrm{MrNV}$ and XSV were associated with WTD in Chinese prawns. The simultaneous presence of more than 1 virus type in diseased crustaceans has previously been reported (Bonami 1980, Mari 1987). XSV has been described as a 'satellite virus' because it does not possess a gene coding for RNA polymerase and must therefore depend on that of $\mathrm{MrNV}$ or possibly another RNA virus for replication (Sri Widada \& Bonami 2004).

In the brooder prawns, both MrNV and XSV could be detected, but the prawns showed no gross signs of disease. A similar type of tolerance has been reported for WSSV in Macrobrachium rosenbergii (Peng et al. 1998, Sahul Hameed et al. 2000) and for yellow head virus (YHV) in this and other palaemonid shrimp (Longyant et al. 2005). Tolerance in the latter is now known to be associated with low expression of the viral coat protein gp116 but not other viral proteins (P. Sithigorngul pers. comm.). As with these other viruses, the mechanism of tolerance to $\mathrm{MrNV}$ and XSV in adult prawns is not known.

The very similar amino acid sequences between Thai $M r N V$ isolates and those reported from elsewhere suggests that all are very closely related. However, it is difficult to surmise at this time whether the close similarity indicates recent dispersal from a common origin. This might be suggested by the fact that the virus was first reported from the French West Indies and then sequentially from China, India and Thailand. On the other hand, it might also be that the disease was not recognized and reported from China, India and Thailand until after the initial report from the French West Indies. The fact that the Thai isolates differ by 3 amino acids from isolates previously reported suggests, at least, that if it was introduced from elsewhere, the introduction was probably not very recent.

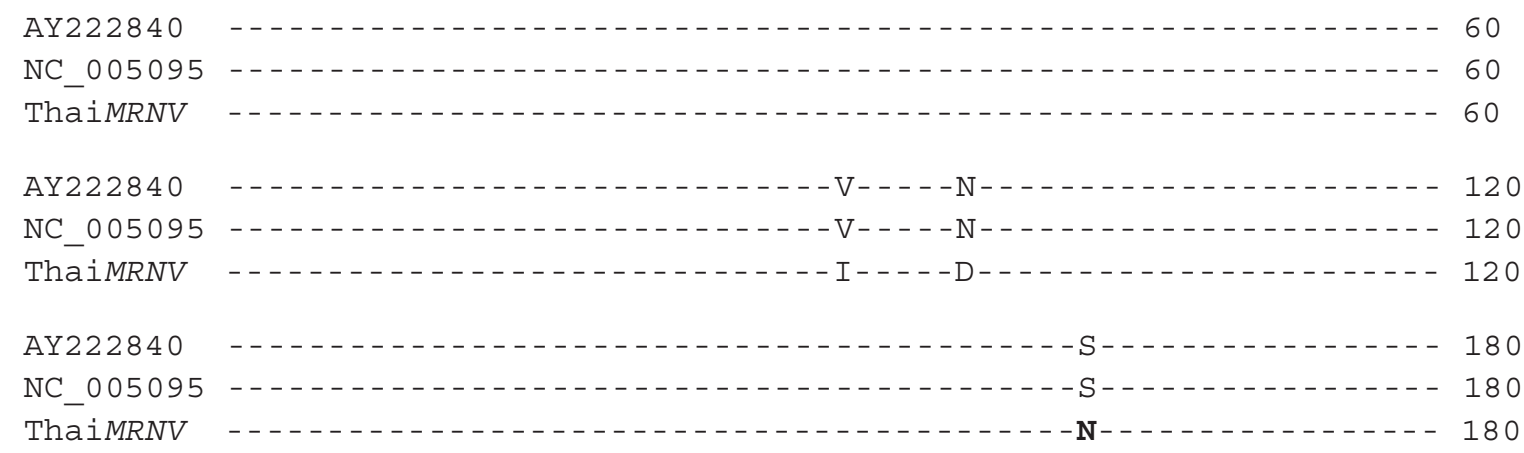

AY222840 - - - - - - - - - 201

NC_005095 - - - - - - - - - - 201

ThaiMRNV -...............-. 201
Fig. 2. Macrobrachium rosenbergii. Comparison of deduced amino acid (aa) sequences of $\mathrm{MrNV}$ capsid protein from various white tail disease (WTD) isolates. The non-conservative aa difference is indicated in bold 
A better knowledge of pathogen distribution in tissues and organs of affected animals helps us to understand pathology and transmission. It also assists in the isolation and detection of pathogens and in development of control measures. Tissue tropism of $\mathrm{MrNV}$ and XSV has been carried out by Sahul Hameed et al. (2004b), whose RT-PCR assays showed that both $\mathrm{MrNV}$ and XSV were present together in all positive tissues and organs. It is now known that XSV is a satellite virus dependent on the RNA-dependent RNA polymerase of $M r N V$ for its replication (Qian et al. 2003). However, it is still not clearly understood whether both viruses are needed to cause WTD or whether $M r N V$ alone is sufficient. Previous reports from India have shown that some WTD samples are positive for XSV only (Sahul Hameed et al. 2004a), and we found WTD samples positive for $\mathrm{MrNV}$ only. It is possible that failure to detect the dual infections was due to the fact that single-step RT-PCR protocols were used.

The presence of $M r N V$ and XSV in brooders suggests that they are likely to transmit the viruses to the larvae and PL they produce, as is common for several penaeid shrimp viruses (Lightner 1996). In the interval while this is being determined, it would probably be prudent to screen brooders for $\mathrm{MrNV}$ and XSV before they are used for PL production.

\section{LITERATURE CITED}

Arcier JM, Herman F, Lightner DV, Redman R, Mari J, Bonami JR (1999) A viral disease associated with mortalities in hatchery-reared postlarvae of the giant freshwater prawn Macrobrachium rosenbergii. Dis Aquat Org 38: 177-181

Bonami JR (1980) Recherches sur les infections virales des crustacés marins: étude des maladies à étiologie simple et complexe chez les Décapodes des côtes françaises. Thése Doctorat d'Etat. Université des Sciences et Techniques du Languedoc, Montpellier 2

Bonami JR, Shi Z, Qian D, Sir Widada J (2005) White tail disease of the giant freshwater prawn, Macrobrachium rosenbergii: separation of the associated virions and characterization of $\mathrm{MrNV}$ as a new type of nodavirus. J Fish Dis 28:23-31

Garzon S, Charpentier G (1992) Nodaviridae. In: Adams JR, Bonami JR (eds) Atlas of invertebrate viruses. CRC Press, Boca Raton, FL, p 351-370

Lightner DV (1996) White spot syndrome baculovirus complex (WSBV). In: Lightner DV (eds) A handbook of pathology and diagnostic procedures for diseases of penaeid shrimp. World Aquaculture Society, Baton Rouge, LA, p 3.11.1-3.11.5

Longyant S, Sithigorngul P, Chaivisuthangkura P, Rukpratanporn S, Sithigorngul W, Menasveta P (2005) Differences in susceptibility of palaemonid shrimp species to yellow head virus (YHV) infection. Dis Aquat Org 64:5-12

Mari J (1987) Recherches sur les maladies virales du Crustacé Décapode marin Carcinus mediterraneus Czerniavsky 1884. Thése de Doctorat, Université de Montpellier 2
Nash G, Chinabut S, Limsuwan C (1987) Idiopathic muscle necrosis in freshwater prawn, Macrobrachium rosenbergii De Man, cultured in Thailand. J Fish Dis 10:109-120

New MB (1990) Freshwater prawn culture: a review. Aquaculture 88:99-143

Peng SE, Lo CF, Ho CH, Chang CF, Kou GH (1998) Detection of white spot baculovirus (WSBV) in giant freshwater prawn, Macrobrachium rosenbergii, using polymerase chain reaction. Aquaculture 164:253-262

Qian D, Shi Z, Zhang S, Cao Z and 5 others (2003) Extra small virus-like particles (XSV) and nodavirus associated with whitish muscle disease in the giant freshwater prawn, Macrobrachium rosenbergii. J Fish Dis 26:521-527

Romestand B, Bonami JR (2003) A sandwich enzyme linked immunosorbent assay (S-ELISA) for detection of $\mathrm{MrNV}$ in the giant freshwater prawn, Macrobrachium rosenbergii (de Man). J Fish Dis 26:71-75

Sahul Hameed AS, Xavier Charles M, Anilkumar M (2000) Tolerance of Macrobrachium rosenbergii to white spot syndrome virus. Aquaculture 183:207-213

Sahul Hameed AS, Yoganandhan K, Sri Widada J, Bonami JR (2004a) Studies on the occurrence of Macrobrachium rosenbergii nodavirus ( $\mathrm{MrNV}$ ) and extra small virus-like particles (XSV) associated with white tail disease (WTD) of Macrobrachium rosenbergii in India by RT-PCR detection. Aquaculture 238:127-133

Sahul Hameed AS, Yoganandhan K., Sri Widada J, Bonami JR (2004b) Experimental transmission and tissue tropism of Macrobrachium rosenbergii nodavirus $(\mathrm{MrNV})$ and its associated extra small virus (XSV). Dis Aquat Org 62: 191-196

Sri Widada J, Bonami JR (2004) Characterization of the monocistronic genome of extra small virus, a virus-like particle associated with Macrobrachium rosenbergii nodavirus: possible candidate for a new species of satellite virus. J Gen Virol 85:643-646

Sri Widada J, Durand S, Cambournac I, Qian D, Shi Z, Dejonghe E, Richard V, Bonami JR (2003) Genome based detection methods of Macrobrachium rosenbergii nodavirus, a pathogen of the giant freshwater prawn, Macrobrachium rosenbergii: dot-blot, in situ hybridization and RT-PCR. J Fish Dis 26:583-590

Sri Widada J, Richard V, Cambournac I, Shi Z, Qian D, Bonami JR (2004) Dot-blot hybridization and RT-PCR detection of extra small virus (XSV) associated with white tail disease of prawn Macrobrachium rosenbergii. Dis Aquat Org 58:83-87

Thompson JD, Higgins DG, Gibson TJ (1994) CLUSTAL W improving the sensitivity of progressive multiple sequence weighting, position specific gap penalties and weight matrix choice. Nucleic Acid Res 22:4673-4680

Tung CW, Wang CS, Chen SN (1999) Histological and electron microscopic study on Macrobrachium muscle virus (MMV) infection in the giant freshwater prawn, Macrobrachium rosenbergii (de Man), cultured in Taiwan. J Fish Dis 22:1-5

Van Regenmortel MHV, Fauquet CM, Bishop DHL, Carstens EB and 7 others (2000) Virus taxonomy: classification and nomenclature of viruses. Seventh Report of the International Committee on Taxonomy of Viruses. Academic Press, San Diego, CA

Yoganandhan K, Sri Widada J, Bonami, JR, Sahul Hameed AS (2005) Simultaneous detection of Macrobrachium rosenbergii nodavirus and extra small virus by a single tube, one-step multiplex RT-PCR assay. J Fish Dis 28:65-69

Submitted: November 7, 2005; Accepted: January 23, 2006

Proofs received from author(s): March 1, 2006 